\title{
Penggunaan Input yang Optimal pada Usaha Tani Kedelai (Suatu Kasus di Desa Sukahurip, Kecamatan Pangatikan, Kabupaten Garut, Jawa Barat)
}

\author{
(The Use of Optimum Inputs in the Soybean Farm (A Case Study in \\ Sukahurip Village, Pangatikan Sub-District, Garut District, West Java))
}

\author{
Eti Suminartika
}

(Diterima April 2018/Disetujui Juni 2020)

\begin{abstract}
ABSTRAK
Kebutuhan kedelai nasional sebagian besar dipenuhi oleh kedelai impor dan kecenderungan impor kedelai terus meningkat. Ketergantungan pada impor berdampak buruk pada ketahanan pangan. Produksi kedelai dalam negeri sangat rendah dan cenderung menurun. Produksi kedelai dalam negeri yang rendah dapat disebabkan oleh penggunaan input yang kurang tepat. Kasus penggunaan input yang belum efisien (optimal) banyak ditemukan di lapangan. Tujuan penelitian ini adalah untuk menganalisis faktor-faktor yang memengaruhi produksi kedelai dan tingkat penggunaan input yang optimal pada usaha tani kedelai. Penelitian dilaksanakan di Desa Sukahurip, Kecamatan Pangatikan, Kabupaten Garut, Jawa Barat pada bulan Juli 2018. Metode penelitian yang digunakan adalah metode survei. Data yang digunakan terdiri atas data primer dan data sekunder. Data primer diperoleh dari petani sampel. Sampel petani diambil secara acak sederhana. Analisis data dilakukan dengan menggunakan Fungsi produksi Cobb Douglas (untuk menganalisis faktor-faktor yang memengaruhi produksi kedelai) dan persamaan nilai produk marjinan (NPM) yang sama dengan biaya korbanan marjinal (BKM) digunakan untuk menentukan tingkat penggunaan input yang optimal. Faktor-faktor yang memengaruhi produksi kedelai adalah lahan dan benih. Penggunaan lahan dan benih belum efisien karena lahan yang terbatas dan pemakaian benih masih di bawah standar. Penambahan input sampai ke tingkat yang optimal, yaitu 1,36 ha lahan dan 52,7 $\mathrm{kg}$ benih, dapat memaksimumkan keuntungan.
\end{abstract}

Kata kunci: efisiensi, input, kedelai, optimal, produksi

\section{ABSTRACT}

The majority of soybean supply is fulfilled by importation and the import of soybean tends to increase. The dependency of Indonesia on imported soybean indeed becomes a serious issue in maintaining food security and local production of soybean is low and quite decreasing. The low domestic soybean production might be caused by the inappropriate used of inputs. Many cases found in the field are the inefficient uses of input factors. The purpose of this study is to analyze the factors influencing the soybean production and to analyze the optimal level of input use in soybean production. The study was conducted in the Sukahurip Village, Pangatikan Sub-District, Garut District, West Java in July 2018. The research method used was a survey method. The data used consisted of primary and secondary data. Primary data were obtained from samples of soybean farmers and samples of farmers were taken by a simple random sampling. The data were analyzed by Cobb Douglass's Production function (to analyze factors affecting soybean production) and the NPM that was equal to BKM formula was used to determine the optimal level of inputs use. Factors influencing soybean production are land and seeds. Land use, seeds, and ZA fertilizer have not been used efficiently because of the limited land use and the use of substandard inputs. The addition of inputs to the optimal level is 1.36 hectares of land use and $52.7 \mathrm{~kg}$ of seeds that will maximize the profits.

Keywords: efficiency, input, optimal, production, soybean

\section{PENDAHULUAN}

Permintaan kedelai dalam negeri mencapai 3,21 juta ton pada tahun 2017 dan sebagian besar kedelai dikonsumsi dalam bentuk pangan olahan, seperti tahu, tempe, kecap, tauco, dan berbagai bentuk makanan ringan. Soetrisno (2010) mengungkapkan bahwa sekitar $95 \%$ kedelai digunakan untuk industri pangan

Fakultas Pertanian Universitas Padjadjaran, Jl. Raya Bandung Sumedang KM.21, Hegarmanah, Kec. Jatinangor, Sumedang 45363

Penulis Korespondensi: Email: eti.suminartika@unpad.ac.id dan dari kedelai yang digunakan untuk produksi pangan tersebut $91 \%$ digunakan untuk produksi tahu dan tempe.

Konsumsi kedelai dipenuhi dari produksi dalam negeri dan impor. Produksi dalam negeri berada di bawah jumlah kebutuhan kedelai nasional. Pada tahun 2017, produksi dalam negeri hanya 542.450 ton sementara kebutuhannya 3,21 juta ton dan kekurangannya dipenuhi melalui kedelai impor sebanyak 2,67 juta ton atau $83,1 \%$ dari kebutuhan dalam negeri. Tendensi jumlah impor kedelai menunjukkan peningkatan dari tahun ke tahun dan hal tersebut menyebabkan Indonesia selalu bergantung pada 
kedelai impor (Susilowati et al. 2013; Perdana et al. 2013).

Banyak faktor yang menyebabkan Indonesia bergantung pada kedelai impor, salah satunya adalah harga kedelai impor yang lebih murah. Rante (2013) mengungkapkan bahwa sistem tata niaga kedelai Indonesia didominasi oleh kedelai impor karena harga kedelai impor yang murah.

Data FAO menunjukkan bahwa rasio antara harga kedelai impor (CIF) dan harga produsen kedelai lokal rata-rata 0,67 (2002-2011), artinya harga kedelai lokal di produsen rata-rata 1,5 kali lebih mahal dibandingkan dengan kedelai impor. Damardjati et al. (2005) melaporkan bahwa harga riil kedelai lokal di pasaran domestik terus menurun.

Harga kedelai lokal yang tidak mampu bersaing dengan kedelai impor menjadi salah satu disinsentif bagi petani dalam meningkatkan areal tanam/panen dan produksi kedelai (Budhi \& Aminah 2010). Rata-rata penurunan luas panen kedelai di Indonesia dan di Pulau Jawa masing-masing sebesar 0,85 dan 4,09\% (2012-2016). Penurunan luas areal tanam dan produksi kedelai di Jawa Barat, masing-masing mencapai 26,8 dan 22,5\% dalam kurun waktu 2014-2016 (Kementan 2017). Penurunan luas areal tanam dan produksi kedelai di Kabupaten Garut (sentra kedua produksi kedelai Jawa Barat) masing-masing sebesar 25,3 dan 21,3\% (2014-2016). Banyak petani di Kabupaten Garut beralih menjadi menanam komoditas lain, seperti jagung hibrida, kacang tanah, atau palawija lain yang lebih menguntungkan (Dinas Pertanian Kabupaten Garut 2017).

Kebergantungan pada impor kedelai akan sangat mengganggu stabilitas industri pangan olahan berbahan baku kedelai serta membuat ketahanan pangan menjadi melemah. Salah satu upaya untuk mengurangi kebergantungan pada impor adalah meningkatkan produksi kedelai dalam negeri melalui upaya ekstensifikasi dan intensifikasi. Upaya ekstensifikasi dilakukan dengan perluasan lahan, namun tampaknya cara ini lebih sulit dilakukan karena adanya alih fungsi lahan pertanian. Langkah yang bisa dilakukan adalah dengan upaya intensifikasi. Upaya intensifikasi dilakukan dengan perbaikan teknologi, seperti penggunaan benih varietas unggul baru.

Peningkatan produksi kedelai dapat dilakukan karena adanya indikasi peningkatan produktivitas kedelai nasional dengan rata-rata pertumbuhan 0,31\% (2003-2013) dan 2,12\%/tahun (2012-2016). Peningkatan produktivitas kedelai di Jawa Barat dan Kabupaten Garut masing-masing sebesar 2,56 dan 6,5\%/tahun (2014-2017). Peningkatan produktivitas yang positif mencerminkan kemajuan teknologi budi daya kedelai yang didukung oleh penggunaan varietas unggul, terutama yang berumur genjah (Irwan 2013; Apriliana et al. 2020).

Kenyataan di lapangan menunjukkan masih banyak petani kedelai yang menggunakan kombinasi dan jumlah input yang kurang tepat. Menurut Dinas Pertanian Kabupaten Garut (2017), salah satu permasalahan petani adalah penerapan teknologi budi daya yang belum optimal. Permasalahan serupa juga dialami oleh petani kedelai di berbagai lokasi, seperti yang diungkapkan oleh Nufus (2004); Rahayu \& Riptanti (2010); Ningsih et al. (2015). Penggunaan jumlah dan kombinasi faktor produksi yang kurang tepat mengakibatkan hasil produksi yang rendah atau biaya yang tinggi, dan hal tersebut mengakibatkan pendapatan petani yang rendah (Soekartawi 1990). Oleh karena itu, perlu didorong penggunaan input yang tepat (tepat waktu, jumlah, mutu, jenis, dan harga) pada usaha tani kedelai.

Seberapa jauh input berpengaruh pada produksi telah disederhanakan dalam suatu fungsi produksi. Fungsi produksi dapat mengukur seberapa besar pengaruh input pada output. Koefisien fungsi produksi dapat mencerminkan tingkat elastisitas produksi (Ep). Nilai elastisitas produksi dapat memberikan petunjuk apakah harus dilakukan penambahan atau pengurangan jumlah input. Elastisitas produksi yang sama dengan nilai satu $(E p=1)$ mengindikasikan bahwa output yang dihasilkan adalah optimal, Doll \& Orazem (1984); Debertin (1986); (Sukirno 2005), menyatakan bahwa tingkat output yang optimal tercapai pada saat nilai produk marginal sama dengan harga input. Kondisi ini mencapai keuntungan yang maksimum. Pada tingkatan itu dapat dikatakan bahwa sumber daya digunakan secara efisien (optimal). Petani tidak akan menambah atau mengurangi penggunaan input pada saat mencapai keuntungan maksimum. Tujuan penelitian ini adalah untuk menganalisis faktor-faktor yang memengaruhi produksi kedelai dan menemukan penggunaan input yang optimal pada usaha tani kedelai.

\section{METODE PENELITIAN}

\section{Populasi dan Sampel}

Penelitian dilaksanakan di Desa Sukahurip, Kecamatan Pangatikan, Kabupaten Garut, Jawa Barat. Penentuan lokasi penelitian dilakukan secara purposive dengan pertimbangan bahwa Jawa Barat merupakan sentra produksi kedelai nasional keempat (berkontribusi 9,4\% pada produksi kedelai nasional). Kabupaten Garut merupakan sentra kedua produksi kedelai di Jawa Barat (berkontribusi 21,7\% pada produksi kedelai Jawa Barat) (Kementan 2017). Kecamatan Pangatikan termasuk di antara sepuluh sentra produksi kedelai di Kabupaten Garut.

Kontribusi kedelai dari Kecamatan Pangatikan pada produksi kedelai Kabupaten Garut tidak begitu banyak, namun memiliki ciri spesifik, yaitu petani kedelai di Kecamatan Pangatikan secara rutin menanam kedelai setiap tahunnya dan tidak pernah beralih menanam tanaman lain. Desa Sukahurip merupakan sentra utama produksi kedelai di Kecamatan Pangatikan (BP3K Kecamatan Pangatikan, Kabupaten Garut). Penelitian dilaksanakan pada bulan Juli 2018. 
Metode yang digunakan dalam penelitian ini adalah metode survei. Jenis data yang digunakan dalam penelitian ini adalah data primer dan sekunder. Data primer diperoleh dari responden petani kedelai dengan teknik sampling. Jumlah populasi petani kedelai di Desa Sukahurip sebanyak 150 orang (BP3K 2017). Jumlah sampel petani diambil dengan menggunakan rumus Slovin (Sevilla et al. 2007) sebagai berikut:

$$
\mathrm{n}=\frac{N}{1+N(e)^{2}}
$$

\section{Keterangan:}

$\mathrm{n}=$ Jumlah sampel

$\mathrm{N}=$ Ukuran populasi

$\mathrm{e}=$ Batas kekeliruan yang dikehendaki tidak lebih dari $10 \%$

Perhitungan:

$$
\begin{gathered}
\mathrm{n}=\frac{N}{1+N(e)^{2}} \\
\mathrm{n}=\frac{150}{1+150(0,10)^{2}}=60
\end{gathered}
$$

Berdasarkan perhitungan di atas, jumlah sampel petani kedelai diambil sebanyak 60 orang. Penentuan sampel petani dilakukan secara acak sederhana (simple random sampling).

Data primer dari petani sampel diperoleh dengan cara wawancara langsung menggunakan bantuan kuesioner. Data sekunder diperoleh dari studi literatur kepustakaan (hasil penelitian dan teori yang digunakan), Kementan (data tingkat nasional mengenai produksi, luas tanam/panen, harga, dan impor), Dinas Pertanian Kabupaten Garut (data tingkat provinsi mengenai produksi, luas tanam/panen, produktivitas, dosis anjuran, dan tingkat penerapan teknologi), BP3K (data tingkat kecamatan mengenai produksi, luas tanam/panen, produktivitas, dosis anjuran, dan tingkat penerapan teknologi), kantor kecamatan (data fisik kecamatan), dan kantor desa (jumlah, nama petani, dan luas lahan).

\section{Definisi Variabel/Konsep}

Dalam penelitian ini variabel/konsep yang digunakan adalah a) Produksi kedelai $(Y)$, yaitu jumlah biji kering kedelai yang dihasilkan petani dan dihitung dalam kuintal per hektar, b) Lahan $\left(X_{1}\right)$, yaitu luas lahan tanam kedelai yang diusahakan petani dan diukur dalam hektar, c) Tenaga kerja $\left(\mathrm{X}_{2}\right)$, yaitu jumlah tenaga kerja (dalam dan luar keluarga) yang digunakan dalam usaha tani kedelai per musim tanam dan diukur dalam hari orang kerja (HOK) per hektar, d) Benih $\left(\mathrm{X}_{3}\right)$, yaitu jumlah benih yang digunakan dalam satu musim tanam dan diukur dalam $\mathrm{kg}$ per hektar, e) TSP $\left(\mathrm{X}_{4}\right)$, yaitu jumlah pupuk TSP yang digunakan dalam satu musim tanam dan diukur dalam $\mathrm{kg}$ per hektar, f) $\mathrm{KCl}\left(\mathrm{X}_{5}\right)$, yaitu jumlah pupuk $\mathrm{KCl}$ yang digunakan dalam satu musim tanam dan diukur dalam kg per hektar, g) Pupuk Urea $\left(\mathrm{X}_{6}\right)$, yaitu jumlah pupuk urea (ZA) yang digunakan dalam satu musim tanam dan diukur dalam kilogram per hektar, h) Pupuk kandang $\left(X_{7}\right)$, yaitu jumlah pupuk kandang yang digunakan dalam satu musim tanam dan diukur dalam kuintal per hektar, i) Fungisida $\left(\mathrm{X}_{8}\right)$, yaitu jumlah fungisida yang digunakan dalam satu musim tanam dan diukur dalam kilogram per ha, dan j) Input optimal, yaitu jumlah penggunaan input pada kondisi yang optimal (efisien), yaitu pada saat hasil marginal sama dengan biaya marginal.

\section{Analisis Data}

Data dianalisis dengan menggunakan analisis ekonometrik dan matematik. Analisis ekonometrik digunakan untuk menganalisis faktor-faktor yang memengaruhi produksi kedelai. Fungsi produksi CobbDouglas digunakan untuk menganalisis faktor-faktor yang memengaruhi produksi kedelai. Fungsi produksi Cobb-Douglas adalah suatu fungsi yang melibatkan dua atau lebih variabel, yang secara matematik dapat dituliskan sebagai berikut (Soekartawi 2003):

$$
\mathrm{Y}=\mathrm{a} \mathrm{X}_{1}^{\mathrm{b} 1}, \mathrm{X}_{2}^{\mathrm{b} 2}, \mathrm{X}_{3}^{\mathrm{b} 3}, \ldots, \mathrm{X}_{\mathrm{n}}^{\mathrm{bn}} \mathrm{e}
$$

Fungsi produksi Cobb-Douglas dalam penyelesaiannya selalu dilogaritmakan dan diubah bentuknya menjadi fungsi linear sebagai berikut:

$\log Y=\log a+b_{1} \log X_{1}+b_{2} \log X_{2}+b_{3} \log X_{3}+b_{4} \log$ $X_{4}+b_{5} \log X_{5}+b_{6} \log X_{6}+b_{7} \log X_{7}+b_{8} \log X_{8}+e$

Keterangan:

$\mathrm{Y}=$ Produksi kedelai (Ku/ha)

$\mathrm{X}_{1}=$ Lahan (ha)

$\mathrm{X}_{2}=$ Tenaga kerja $(\mathrm{HOK} / \mathrm{ha})$

$X_{3}=\operatorname{Benih}(\mathrm{kg} / \mathrm{ha})$

$X_{4}=$ Pupuk TSP $(\mathrm{kg} / \mathrm{ha})$

$X_{5}=$ Pupuk KCl $(\mathrm{kg} / \mathrm{ha})$

$X_{6}=$ Pupuk ZA $(\mathrm{kg} / \mathrm{ha})$

$\mathrm{X}_{7}=$ Pupuk kandang $(\mathrm{Ku} / \mathrm{ha})$

$\mathrm{X}_{8}=$ Fungisida $(\mathrm{kg} / \mathrm{ha})$

Kebaikan model (goodness of fit) di atas dapat diukur dengan menggunakan koefisien determinasi $\left(R^{2}\right)$. Koefisien determinasi mengukur persentase total variasi $Y$ yang dijelaskan oleh variabel $X$ dengan rumus sebagai berikut:

$$
\mathrm{R}^{2}=\frac{\mathrm{ESS}}{\mathrm{TSS}}
$$

Keterangan:

ESS = Explained Sum of Squares

TSS $=$ Total Sum of Squares 
Nilai $\mathrm{R}^{2}$ sama dengan satu artinya ada kecocokan sempurna dan nilai $R^{2}$ sama dengan nol artinya tidak ada hubungan antara variabel $Y$ dan X (Gujarati 1978).

Pengaruh secara serempak variabel bebas pada variabel terikat dianalisis dengan menggunakan uji $F$ (Gujarati 1978):

$$
F_{\text {hit }}=\frac{R^{2} /(k-1)}{\left(1-R^{2}\right) /(n-k)}
$$

Keterangan:

$\mathrm{R}^{2}=$ Koefisien determinasi

$\mathrm{n}=$ Jumlah sampel

$\mathrm{k}=$ Jumlah parameter di dalam model

Kaidah pengambilan keputusannya adalah:

Jika $F_{\text {hit }}>\mathrm{F}_{\text {tabel, }}$ maka terima Ha tolak Ho

Jika $\mathrm{F}_{\text {hit }}<\mathrm{F}$ tabel, maka terima $\mathrm{Ho}$ tolak $\mathrm{Ha}$

$\mathrm{H}_{\mathrm{o}}=$ Penggunaan faktor-faktor produksi kedelai secara serempak tidak berpengaruh nyata

$\mathrm{H}_{\mathrm{a}}=$ Penggunaan faktor-faktor produksi kedelai secara serempak berpengaruh nyata

Uji $\mathrm{T}$ digunakan untuk menganalisis pengaruh secara parsial antara variabel bebas dan variabel terikat (Gujarati 1978) dengan rumus sebagai berikut:

$$
\mathrm{t}_{\text {hit }}=\frac{b 1}{S b 1}
$$

Kaidah pengambilan keputusannya adalah:

Jika $t$ hit $>t$ tabel, maka terima $\mathrm{Ha}$ tolak $\mathrm{Ho}$

Jika $t$ hit $<\mathrm{t}$ tabel, maka terima $\mathrm{Ho}$ tolak $\mathrm{Ha}$

$\mathrm{H}_{\mathrm{o}}: b=0$

$\mathrm{H}_{\mathrm{a}}: b \neq 0$

\section{Data Diolah Menggunakan Bantuan Software SPSS}

Penggunaan input yang optimal dianalisis menggunakan analisis matematis, persamaan matematis yang digunakan adalah persamaan NPM = BKM, yaitu kondisi ketika keuntungan maksimum tercapai dan tercapai efisiensi penggunaan faktor produksi (Sukartawi 2003). Biaya korbanan marginal merupakan harga input $\left(\mathrm{Px}_{\mathrm{i}}\right)$. Perhitungan $\frac{\mathrm{NPMxi}}{\mathrm{Pxi}}$ menghasilkan tiga tingkatan efisiensi, yaitu:

$\frac{\mathrm{NPMxi}}{\mathrm{Pxi}}>1$, artinya penggunaan input $\mathrm{x}$ masih belum efisien dan perlu penambahan input

$\frac{\mathrm{NPMxi}}{\mathrm{Pxi}}=1$, artinya penggunaan input $\mathrm{x}$ sudah efisien dan tidak perlu penambahan/pengurangan input

$\frac{\mathrm{NPMxi}}{\mathrm{Pxi}}<1$, artinya penggunaan input $x$ tidak efisien dan perlu mengurangi penggunaan input

Penggunaan input yang optimal berada di kondisi kedua, yaitu ketika rasio $N P M_{x i}$ dengan $P_{x i}$ sama dengan satu. Nilai Produk Marginal (NPM) merupakan perkalian Produk Marginal (PM) dengan harga output
$\left(P_{Y}\right)$, sementara PM merupakan rasio antara tambahan output $(\Delta \mathrm{Y})$ dan tambahan input $(\Delta \mathrm{X})$ dan PM dapat diperoleh dari perkalian koefisien regresi $\left(b_{i}\right)$ dengan $(\mathrm{Y} / \mathrm{X})$. Secara matematis, nilai produk marginal dapat ditulis: $\mathrm{NPMxi}=\frac{\text { bi.Y.PYY }}{\mathrm{Xi}}$ dan ketika persamaan $\mathrm{NPMx}_{\mathrm{i}}$ sama dengan $\mathrm{Px}_{\mathrm{i}}$ maka persamaan dapat ditulis: $\frac{\text { bi.Y.PY }}{\mathrm{Xi}}=\mathrm{Pxi}$ atau $\frac{\text { bi.Y.PY }}{\mathrm{Xi.Pxi}}=1$

Keterangan:

NPMx = Nilai produk marjinal

$\mathrm{b} \quad=$ Koefisien regresi

$\mathrm{Y} \quad$ = Rata-rata jumlah produksi kedelai $(\mathrm{kw})$

$\mathrm{X}_{\mathrm{i}} \quad=$ Rata-rata jumlah input kedelai ke-i $(\mathrm{kg})$

$\mathrm{P}_{\mathrm{Y}} \quad=$ Harga kedelai $(\mathrm{Rp} / \mathrm{kg})$

$\mathrm{P}_{\mathrm{Xi}} \quad=$ Harga input ke-i (Rp/kg)

Penentuan tingkat penggunaan input yang optimal $\left(X_{i}\right)$ dapat dilakukan dengan menggunakan persamaan di atas.

\section{HASIL DAN PEMBAHASAN}

Karakteristik petani kedelai di lokasi penelitian meliputi rata-rata umur petani kedelai, yaitu 47,6 tahun (yang termasuk ke dalam golongan umur produktif). Pendidikan petani umumnya tamat sekolah dasar (pendidikan relatif rendah). Rata-rata luas lahan yang dimiliki oleh petani adalah sekitar 1,26 ha, yang sekitar 0,39 ha merupakan usaha tani kedelai, sedangkan rata-rata lahan kebun nonkedelai (jagung, cabai, ubi kayu, dan lain-lain) adalah 0,76 ha yang hanya dikerjakan oleh $37 \%$ petani kedelai, dan selebinya $63 \%$ tidak memiliki kebun nonkedelai. Rata-rata luas lahan sawah petani kedelai adalah 0,11 ha dan diusahakan oleh $88,6 \%$ petani kedelai. Petani kedelai di Desa Sukahurip rata-rata berumur produktif, pendidikannya rendah, berlahan sempit, sumber pendapatannya berasal dari usaha tani kedelai, padi, dan palawija lainnya.

\section{Faktor-faktor yang Memengaruhi Produksi Kedelai}

Faktor-faktor yang memengaruhi produksi kedelai dianalisis dengan menggunakan fungsi produksi CobbDouglas. Fungsi produksi Cobb-Douglas sering dipakai oleh para peneliti. Hal ini disebabkan karena kemudahan-kemudahan yang dimilikinya. Fungsi produksi Cobb-Douglas sering diselesaikan dengan menggunakan cara regresi berganda atau regresi sederhana. Langkah awal untuk mengestimasi model fungsi produksi adalah dilakukan uji koefisien determinasi $\left(R^{2}\right)$ dan uji $F$. Uji $R^{2}$ digunakan untuk mengetahui keragaan variabel $Y$ yang diterangkan oleh variabel $X$.

Hasil analisis menunjukkan bahwa nilai koefisien determinasi $\left(R^{2}\right)$ dalam model yang digunakan adalah 0,890 , artinya keragaan produksi kedelai $(Y)$ dapat dijelaskan oleh variabel lahan, tenaga kerja, benih, 
pupuk TSP, KCL, ZA, pupuk kandang, dan fungisida sebanyak $89,0 \%$ sehingga sisanya $10,1 \%$ dijelaskan oleh variabel lain di luar model. Hasil uji $F$ menunjukkan hasil $F_{\text {hitung }}$ sebesar 49,1, sementara $F_{\text {tabel }}=2,99$, dengan demikian nilai $F_{\text {hit }}>F_{\text {tabel, maka artinya } H_{0}}$ ditolak dan $\mathrm{H}_{\mathrm{a}}$ diterima. Hal tersebut mengindikasikan bahwa penggunaan faktor-faktor produksi secara serempak berpengaruh secara nyata pada produksi kedelai.

Pengaruh secara parsial antara variabel bebas $\left(X_{i}\right)$ dan variabel terikat $(Y)$ dianalisis dengan menggunakan uji-T. Hasil estimasi menunjukkan bahwa lahan dan benih berpengaruh nyata pada produksi kedelai, sementara tenaga kerja, pupuk TSP, dan $\mathrm{KCl}$ tidak berpengaruh nyata pada produksi kedelai. Pupuk urea $(\mathrm{Za})$, pupuk kandang, dan fungisida bertanda negatif yang artinya penambahan faktor produksi tersebut dapat menurunkan produksi kedelai.

Lahan bertanda positif dan berpengaruh secara nyata pada produksi kedelai. Hal ini dapat dilihat dari nilai t-ratio $(=2,31)$ yang lebih besar dari t-tabel $(1,960)$ pada taraf nyata $5 \%$. Koefiesien lahan bernilai 1,04 , artinya setiap adanya penambahan lahan sebesar $1 \%$ akan meningkatkan produksi kedelai sebesar 1,04\% (Tabel 1) asumsi cateris paribus. Hal tersebut menunjukkan bahwa peningkatan produksi kedelai di Desa Sukahurip sangat responsif terhadap penggunaan luas lahan. Hasil tersebut sejalan dengan penelitian Nufus (2004); Rahayu \& Riptanti (2010). Hal tersebut dikarenakan penggunaan lahan kedelai oleh petani di Desa Sukahurip masih sedikit. Penambahan lahan masih rasional untuk dilakukan karena lahan yang diusahakan masih sempit, yaitu rata-rata 0,39 ha/petani. Lahan yang digunakan untuk menanam kedelai adalah lahan kering (kebun).

Benih kedelai bertanda positif dan berpengaruh secara nyata pada produksi kedelai. Hal ini dapat dilihat dari nilai t-ratio $(1,660)$ yang lebih besar dari ttabel $(1,650)$ pada taraf nyata $10 \%$. Koefiesien lahan

Tabel 1 Estimasi fungsi produksi kedelai

\begin{tabular}{lrrr}
\hline \multicolumn{1}{c}{ Variabel } & \multicolumn{1}{c}{$\beta$} & \multicolumn{1}{c}{$\begin{array}{l}\text { Std. } \\
\text { error }\end{array}$} & \multicolumn{1}{c}{ t-hit } \\
\hline Konstanta & 12,805 & 2,795 & 4,585 \\
Lahan & $* * 1,039$ & 0,449 & 2,310 \\
Tenaga kerja & 0,271 & 0,357 & 0,761 \\
Benih & $* 0,100$ & 0,060 & 1,660 \\
TSP & 0,010 & 0,413 & 0,072 \\
KCl & 0,085 & 0,385 & 0,150 \\
Za & $-0,643$ & 0,486 & $-1,324$ \\
P kandang & $-0,332$ & 0,213 & $-1,555$ \\
Fungisida & $-0,460$ & 0,219 & $-2,100$ \\
F hitung & 49,100 & & \\
F tabel (99\%) & 2,99 & & \\
t tabel (99\%) & 2,576 & & \\
t tabel (95\%) & 1,96 & & \\
t tabel (90\%) & 1,645 & & \\
R & 0,89 & & \\
Signifikansi: & & & \\
a 0,01 & $* * *$ & & \\
a 0,05 & $* *$ & & \\
a 0,10 & $*$ & & \\
\hline
\end{tabular}

bernilai 0,100 artinya setiap ada penambahan penggunaan benih sebesar $1 \%$ maka akan meningkatkan produktivitas kedelai sebesar $0,100 \%$ (Tabel 1 ) asumsi cateris paribus. Hal tersebut menunjukkan bahwa peningkatan produksi kedelai di Desa Sukahurip responsif terhadap penggunaan jumlah benih. Hasil tersebut sejalan dengan penelitian Nufus (2004); Ningsih et al. (2015); Apriliana (2020). Hal tersebut dapat dikarenakan penggunaan jumlah benih kedelai oleh petani di Desa Sukahurip masih belum mencapai anjuran maksimal yang diberikan oleh penyuluh. Penggunaan benih yang dianjurkan adalah sebesar 60 $\mathrm{kg} / \mathrm{ha}$, sedangkan di lapang petani rata-rata masih menggunakan benih sejumlah $42,39 \mathrm{~kg} / \mathrm{ha}$. Penambahan benih masih rasional untuk dilakukan karena masih berada di bawah standar. Benih yang digunakan mayoritas petani adalah benih unggul Argomulyo.

Tenaga kerja, TSP, dan $\mathrm{KCl}$ berpengaruh positif pada produksi kedelai, namun tidak berpengaruh secara signifikan pada hasil produksi kedelai. Hal tersebut terjadi karena penggunaan tenaga kerja, TSP, dan $\mathrm{KCl}$ sudah melebihi dosis anjuran. Variabel ZA, pupuk kandang, dan fungisida bertanda negatif artinya penambahan variabel tersebut justru menurunkan produksi kedelai karena penggunaannya sudah sangat berlebih. Salah satu contoh penggunaan pupuk ZA oleh petani adalah $244,5 \mathrm{~kg}$ sementara dosis anjuran adalah $100 \mathrm{~kg}$.

Dari hasil estimasi fungsi produksi Cobb-Douglas dalam bentuk fungsi linear diperoleh hasil sebagai berikut:

$\log Y=\log 12,805+1,039 \log X_{1}{ }^{* *}+0,271 \log X_{2}+$ $0,100 \log X_{3}{ }^{*}+00,010 \log X_{4}+$

$0,085 \log X_{5}-0,643 \log X_{6}-0,332 \log X_{7}-0,460 \log X_{8}$ $+\mathrm{e}$

Pada persamaan tersebut terlihat bahwa nilai $b_{1}, b_{2}$, dan $b_{3}$ adalah tetap walaupun variabel yang terlibat telah diubah menjadi bentuk logaritma. Hal ini demikian karena $b_{1}, b_{2}$, dan $b_{3}$ pada model fungsi Cobb-Douglas sekaligus menunjukkan nilai elastisitas $X_{i}$ terhadap $Y$ (Soekartawi 2003). Nilai koefisien tersebut selanjutnya digunakan dalam persamaan matematis untuk menganalisis efisiensi harga.

\section{Efisiensi Penggunaan Input}

Hasil pendugaan fungsi produksi dapat digunakan untuk menganalisis tingkat efisiensi. Menurut Soekartawi (2003), efisiensi harga atau efisiensi alokatif menggambarkan hubungan antara tingkat penggunaan faktor produksi untuk mencapai keuntungan maksimum dengan memerhatikan hargaharga faktor produksi dan harga produk. Efisiensi harga dapat ditempuh dengan membeli faktor produksi pada saat harga yang murah dan menjual hasil produksi pada saat harga yang relatif tinggi sehingga diperoleh keuntungan yang maksimal.

Keadaan penggunaan faktor produksi apakah sudah mencapai tingkat efisien atau belum, menurut 
Soekartawi (2003) hal tersebut dapat dilihat dari rasio antara nilai produk marginal (NPM) dan harga input $(P x)$. Efisiensi harga (alokatif) dicapai pada saat nilai produk dari masing-masing input sama dengan biaya marjinalnya. Situasi seperti ini akan terjadi apabila petani mampu membuat suatu upaya agar nilai produk marginal (NPM) untuk satu input sama dengan harga input $(\mathrm{Px})$. Persamaan tersebut ditulis $\mathrm{NPM}_{\mathrm{xi}}=\mathrm{P}_{\mathrm{xi}}$. Nilai NPM adalah: $\frac{\text { b.Y.PY }}{\mathrm{X}}$, yaitu koefisien 'bi' merupakan nilai elastisitas produksi dari fungsi produksi. Rasio $N P M_{x i} / P_{x i}$ menghasilkan tingkat effisiensi penggunaan faktor produksi.

Contoh untuk menghitung efisiensi penggunaan benih adalah sebagai berikut. Hasil estimasi fungsi produksi Cobb-Douglass diperoleh nilai koefisien benih 'b4' sebesar 0,100, jumlah rata-rata produksi kedelai (Y) sebesar 855,33 kg, harga kedelai (PY) sebesar Rp. 6.158, rata-rata penggunaan benih $\left(X_{4}\right)$ sebesar 42,39 $\mathrm{kg}$, harga benih $\left(\mathrm{P}_{\mathrm{xi}}\right)$ sebesar $\mathrm{Rp}$. 10.000, dan komponen-komponen tersebut dimasukkan ke dalam persamaan berikut:

$$
\begin{gathered}
\mathrm{NPM}=\frac{\text { b.Y.PY }}{\mathrm{X}}=\frac{(0,100) \cdot(855,33) \cdot(6158)}{\mathrm{X} 42,39}=12 \cdot 423 \\
\text { Efisiensi }=\frac{(\mathrm{NPM})}{\mathrm{pX}}=\frac{(12.423)}{10.000}=1,242
\end{gathered}
$$

Hasil perhitungan nilai efisiensi benih lebih besar dari satu, yaitu sebesar 1,242 yang artinya belum efisien. Penggunaan benih kedelai oleh petani di Desa Sukahurip yang belum efisien memerlukan penambahan jumlah benih agar tercapai efisiensi penggunaannya. Penggunaan benih yang belum efisien dikarenakan petani menggunakan benih di bawah dosis anjuran. Perhitungan yang sama dilakukan untuk input lainnya, seperti pada Tabel 2.

Dari Tabel 2 terlihat bahwa nilai efisiensi lahan $\left(X_{1}\right)$, benih $\left(X_{3}\right)$, dan $\mathrm{KCl}\left(X_{5}\right)$ lebih besar dari satu artinya bahwa penggunaan lahan, benih, dan $\mathrm{KCl}$ belum efisien. Dengan demikian, penggunaan lahan dan benih perlu ditambah. Hasil tersebut sejalan dengan penelitian Nufus (2004) yang menyimpulkan bahwa penggunaan lahan dan benih belum efisien pada usaha tani kedelai di Lombok Barat. Penambahan $\mathrm{KCl}$ dapat meningkatkan produksi kedelai, namun tidak signifikan. Apabila kita lihat nilai efisiensi untuk tenaga kerja $\left(X_{2}\right)$, TSP $\left(X_{4}\right)$, ZA $\left(X_{6}\right)$, pupuk kandang $\left(X_{7}\right)$, dan fungisida $\left(X_{8}\right)$ semuanya adalah kurang dari satu, artinya tidak efisien sehingga penggunaan input tersebut perlu dikurangi. Hasil tersebut sejalan dengan penelitian Rahayu \& Riptanti (2010); Nufus (2004). Hal tersebut dikarenakan pengunaan input tersebut sudah berlebih. Penggunaan TSP, $\mathrm{KCl}$, dan ZA oleh petani kedelai di Desa Sukahurip masing-masing sebanyak $113,51 \mathrm{~kg}, 57,92 \mathrm{~kg}$, dan $244,5 \mathrm{~kg}$, sementara dosis anjuran berada di bawahnya, masing-masing sebesar $100 \mathrm{~kg}, 50 \mathrm{~kg}$, dan $100 \mathrm{~kg}$ (Dinas Pertanian Kabupaten Garut. 2017).

\section{Penggunaan Input Optimal}

Penggunaan input yang optimal tercapai pada saat keuntungan adalah maksimum, dan keuntungan maksimum tercapai pada saat nilai produk marginal sama dengan harga input (Doll \& Orazem 1984; Debertin 1986; Sukartawi 2003). Persamaan matematis yang digunakan untuk menghitung penggunaan input yang optimal adalah persamaan NPM=BKM yang selanjutnya diturunkan sehingga diperoleh nilai efisiensi alokatif (harga) (Sukartawi 2003). Kondisi efisien yang dihasilkan dari persamaan efisiensi alokatif dapat menghasilkan jumlah penggunaan input yang optimal. Komponen persamaan efisiensi alokatif mengandung nilai koefisien regresi hasil pendugaan dari fungsi produksi Cobb-Doglass, dan nilai koefisien fungsi tersebut menunjukkan nilai elastisitas yang menunjukkan derajat kepekaan output terhadap input secara teknis. Persamaan efisiensi tersebut juga melibatkan harga input dan output.

Keberhasilan usaha tani dapat diukur secara teknis dan ekonomis. Menurut Soekartawi (2003), efisiensi harga (ekonomis) digunakan untuk mengukur tingkat keberhasilan pelaku usaha dalam mencapai keuntungan maksimum, efisiensi harga tercapai pada saat nilai produk marginal dari masing-masing input sama dengan biaya marjinalnya. Titik keuntungan maksimum adalah titik ketika penggunaan input oleh petani efisien karena sumber daya digunakan secara optimal. Petani tidak perlu menambah ataupun mengurangi penggunaan input pada saat keuntungan maksimum tercapai karena tambahan biaya sama dengan tambahan output yang dihasilkan. Apabila kondisi belum efisien maka perlu menambah penggunaan faktor produksi dan apabila sudah tidak efisien maka perlu pengurangan faktor produksi (Sukartawi 2003)

Langkah awal untuk menghitung tingkat penggunaan input yang optimal adalah mengkondisikan tingkat efisiensi harga dalam keadaan efisien. Berikut dijabarkan penurunan matematis untuk menghitung

\begin{tabular}{|c|c|c|c|c|c|c|}
\hline Variabel & $\beta$ & $\mathrm{x}$ & NPM & Px (Rp/sat) & Efisiensi & Status \\
\hline Lahan & 1,039 & 1,00 & 5.475 .739 & 4000.000 & 1,368 & Belum efisien \\
\hline Tenaga kerja & 0,271 & 88,99 & 16.049 & 50.000 & 0,320 & Tidak efisien \\
\hline Benih & 0,100 & 42,39 & 12.423 & 10.000 & 1,243 & Belum efisien \\
\hline TSP & 0,030 & 113,51 & 1.392 & 2.500 & 0,557 & Tidak efisien \\
\hline $\mathrm{KCl}$ & 0,058 & 57,92 & 5.277 & 3.000 & 1,759 & Belum efisien \\
\hline $\mathrm{Za}$ & $-0,064$ & 244,50 & -1.385 & 2.000 & $-0,692$ & Tidak efisien \\
\hline Pupuk kandang & $-0,332$ & 160,00 & -10.935 & 5.500 & $-1,988$ & Tidak efisien \\
\hline Fungisida & $-0,460$ & 7,23 & -335.310 & 85.000 & $-3,944$ & Tidak efisien \\
\hline
\end{tabular}

Tabel 2 Efisiensi input produksi kedelai 
input yang optimal $\left(X_{i}\right)$. Kondisi efisien dari efisiensi harga adalah $\mathrm{NPMx}_{\mathrm{i}}=\mathrm{Px}_{\mathrm{i}}$ atau dapat ditulis: $N P M_{x} / P_{x i}=1$. Nilai Produk Marginal (NPM) merupakan perkalian matematis Produk Marginal (PM) dengan harga output $\left(\mathrm{P}_{\mathrm{Y}}\right)$, PM merupakan rasio dari tambahan output $(\Delta \mathrm{Y})$ dan tambahan input $(\Delta \mathrm{X}), \mathrm{PM}_{\mathrm{xi}}$ dapat diperoleh dari perkalian koefisien regresi (b) dengan $\left(\mathrm{Y} / \mathrm{X}_{\mathrm{i}}\right)$, yang secara matematis nilai produk marginal dapat ditulis: $\mathrm{NPMxi}=\frac{\text { bi.Y.PYY }}{\mathrm{Xi}}$. Keuntungan maksimum dapat ditulis sebagai berikut: $\frac{\text { bi.Y.PY }}{\mathrm{Xi}}=\mathrm{Pxi}$ atau $\frac{\text { bi.Y.P. }}{\mathrm{Pxi}_{\mathrm{Y}}}=$ $X_{i}$

Penggunaan input yang optimal $\left(X_{i}\right)$ dapat dihitung dengan menggunakan persamaan tersebut. Contoh perhitungan penggunaan benih yang optimal adalah sebagai berikut. Nilai $b_{1}(0,100)$, rata-rata produksi kedelai $(855,53 \mathrm{~kg})$, harga kedelai (Rp.6.158), dan harga benih (Rp10.000/kg), dan semua komponen tersebut dimasukkan ke dalam persamaan berikut:

$$
X_{i}=\frac{\text { bi.Y.P. }}{\text { Pxi }}=\frac{(0,100) \cdot(855,53) \cdot(6158)}{10 \cdot 000}=52,70
$$

Hasil perhitungan jumlah benih optimal adalah sebanyak $52,70 \mathrm{~kg}$, seperti yang disajikan pada Tabel 3. Kenyataan di lapangan, petani kedelai di Desa Sukahurip menggunakan benih kedelai di bawah dosis anjuran (atau belum optimal), yaitu petani menggunakan benih kedelai sebanyak $42,39 \mathrm{~kg} / \mathrm{ha}$ sementara dosis anjuran adalah sebanyak 60/ha. Keuntungan maksimum akan tercapai jika benih yang digunakan jumlahnya optimal, yaitu sebanyak 52,70 $\mathrm{kg}$. Hal yang serupa dilakukan untuk menghitung penggunaan lahan yang optimal.

Lahan kedelai yang diusahakan oleh petani di Desa Sukahurip adalah lahan kering dengan kontur berbukit dan lahan yang diusahakan untuk usaha tani kedelai tergolong sempit, yaitu seluas 0,39 ha. Hasil pendugaan fungsi produksi menunjukkan bahwa penambahan luas areal akan meningkatkan produksi kedelai secara signifikan. Penambahan luas lahan yang secara terus menerus tidak serta merta akan menaikkan produksi, namun akan terkendala oleh faktor lain yang sifatnya terbatas, seperti kandungan hara mikro di dalam tanah. Kondisi demikian dikenal dengan hukum kenaikan hasil yang semakin berkurang (the law of diminishing return) (Sukirno 2005). Penggunaan lahan diupayakan sampai ke titik di mana keuntungan maksimum tercapai, dan hal ini terjadi pada saat tambahan hasil per hektar lahan kedelai sama dengan harga sewa lahan per hektar. Kondisi ini akan dicapai jika petani kedelai di Desa Sukahurip meningkatkan areal tanamnya dari $0,39-1,36$ ha (Tabel 3). Perluasan areal tanam dapat dilakukan dengan menanami lahan yang kurang dimanfaatkan.

\section{KESIMPULAN}

Faktor-faktor yang memengaruhi produksi kedelai adalah lahan dan benih. Penggunaan lahan dan benih
Tabel 3 Penggunaan input optimal

\begin{tabular}{lrrrrr}
\hline Input & $\begin{array}{r}\text { Harga } \\
\text { kedelai } \\
(\mathrm{Rp} / \mathrm{kg})\end{array}$ & $\begin{array}{c}\text { Harga } \\
\text { Input } \\
\text { (Rp/sat) }\end{array}$ & $\begin{array}{c}\text { Input } \\
\text { optimal }\end{array}$ & $\begin{array}{r}\text { Input } \\
\text { aktual }\end{array}$ & $\begin{array}{c}\text { Dosis } \\
\text { anjuran } \\
(\mathrm{kg})\end{array}$ \\
\hline Lahan & 6.158 & 4.000 .000 & 1,36 & 0,39 & - \\
benih & 6.158 & 10.000 & 52,70 & 42,39 & 60 \\
\hline
\end{tabular}

belum efisien karena lahan yang terbatas dan pemakaian benih masih di bawah standar serta luas areal tanam dan benih yang digunakan masih belum optimal. Petani kedelai di Sukahurip perlu menambah luas areal tanam kedelai hingga mencapai 1,36 ha dan menambah pengunaan benih sampai $52,7 \mathrm{~kg} / \mathrm{ha}$ untuk memperoleh keuntungan yang maksimum. Penggunaan TSP, $\mathrm{KCl}$, ZA, pupuk kandang, dan fungisida seyogianaya dikurangi.

\section{DAFTAR PUSTAKA}

Apriliana H, Winandi R, Pambudy R. 2020. Pengaruh Pengelolaan Tanaman Terpadu terhadap Efisiensi Teknis Kedelai. Jurnal IImu Pertanian Indonesia. 25(2): 261-269. https://doi.org/10.18343/ jipi.25.2.261

[BP3K] Balai Penyuluhan Pertanian, Perikanan dan Kehutanan Kecamatan Pangatikan Kabupaten Garut. 2017. Programa Penyuluhan Pertanian, Perikanan dan Kehutanan Kecamatan Pangatikan Tahun 2017.

Budhi GS, Aminah M. 2010. Swasembada Kedelai antara Harapan dan Kenyataan. Forum Penelitian Agro Ekonomi. 28(1): 55-68. https://doi.org/ $10.21082 /$ fae.v28n1.2010.55-68

Damardjati DS, Marwoto DKS, Swastika DM, Arsyad, Hilman Y. 2005. Prospek dan Arah Pengembangan Agribisnis Kedelai. Jakarta (ID): Badan Litbang Pertanian.

Debertin DL. 1986. Agricultural Production Economics. New York (US): Macmillan Publishing Company

Dinas Pertanian Kabupaten Garut. 2017. Laporan Tahunan Dinas Pertanian Kabupaten Garut Tahun 2017. Garut (ID).

Doll JP, Orazem F. 1984. Production Economics: Theory and Application. New York (ID): John Wiley \& Sons.

Gujarati D. 1978. Basic Econometrics. New York (ID): McGraww-Hill Book Company.

Irwan. 2013. Faktor Penentu Keputusan Petani dalam Memilih Varietas Benih Kedelai di Kabupaten Pidie. Agrisep. 14(1): 10-18.

[Kementan] Kementrian Pertanian. 2017. Outlook Komoditas Pertanian Sub Sektor Tanaman Pangan (Kedelai). Pusat Data dan Sistem Informasi Pertanian Kementrian Pertanian Tahun 2017. 
Ningsih IM, Dwiastuti R, Suhartini. 2015. Determinan Efisiensi Teknis Usaha Tani Kedelai. Jurnal Manajemen \& Agribisnis. 12(3): 216-225. https:// doi.org/10.17358/JMA.12.3.216

Nufus N. 2004. Estimasi Fungsi Produksi dan Efisiens Alokasi Sumber Daya Petani Kedelai di Kabupaten Lombok Barat. Agrisep. 2(2): 145-148. https:// doi.org/10.31186/jagrisep.3.1.145-148

Perdana RP, Koestiono D, Syafrial. 2013. Dampak Kebijakan Ekonomi Kedelai terhadap Kinerja Perkedelaian Indonesia. Habitat. 24(2): 120-132.

Rahayu W, Riptanti EW. 2010. Analisis Efisiensi Ekonomi Penggunaan Faktor-faktor Produksi pada Usaha tani Kedelai di Kabupaten Sukoharjo. Caraka Tani. XXV(1): 119-125. https://doi.org/ 10.20961/carakatani.v25i1.15758

Rante Y. 2013. Strategi Pengembangan Tanaman Kedelai untuk Pemberdayaan Ekonomi Rakyat di Kabupaten Keerom Provinsi Papua. Jurnal Manajemen dan Kewirausahaan. 15(1): 75-88. https://doi.org/10.9744/jmk.15.1.75-88
Sevilla, Consuelo G, Jesus A Ochave and Twila G Punsalan. 2007. Research methods. Quezon City $(\mathrm{PH})$ : Rey Printing Company.

Sukartawi. 2003. Teori Ekonomi Produksi Dengan Pokok Bahasan Analisis Fungsi Cobb Douglas. Cetakan ke-3. Jakarta (ID): Rajawali Pers.

Sukartawi. 1990. Teori Ekonomi Produksi, dengan Pokok Bahasan Analisis Fungsi Produksi CobbDouglas (Cetakan Pertama). Jakarta (ID): CV Rajawali.

Soetrisno. 2010. Rancang Bangun Hulu Hilir, Pemodelan dan Kebijakan Pemerintah pada Agribisnis Kedelai. Jurnal Sosial Ekonomi Pertanian. 4(3): 44-58.

Sukirno. 2005. Mikro Ekonomi Teori Pengantar (Edisi ketiga). Jakarta (ID): PT Raja Grafindo Persada.

Susilowati E, Oktaviani R, Arifin B, Arkeman Y. 2013. The Decrease of Production of Indonesian Soybeans and Efforts to Ensure the Certainty of the Vegetable Protein Supply: a Literature Review. International Journal of Information Technology and Business Management. 9(1): 1-5. 